\title{
Ethnic Plurality and Nation Building Process: A Comparative Analysis between Rukun Negara, Bangsa Malaysia and 1Malaysia Concepts as Nation Building Programs in Malaysia
}

\author{
Mujibu Abd Muis ${ }^{1}$, Badrul Azmier Mohamed@ Bakar $^{2}$, Azlan Abdul Rahman ${ }^{3}$, Zaherawati Zakaria ${ }^{2}$, Nazni \\ Noordin ${ }^{2}$, Jennifah Nordin ${ }^{4} \&$ Mahazril 'Aini Yaacob ${ }^{2}$ \\ ${ }^{1}$ Faculty of Administrative Science \& Policy Studies, Universiti Teknologi MARA Terengganu, Dungun, \\ Malaysia \\ ${ }^{2}$ Faculty of Administrative Science \& Policy Studies, Universiti Teknologi MARA Kedah, Merbok, Malaysia \\ ${ }^{3}$ Academy of Language Studies, Universiti Teknologi MARA Kedah, Merbok, Malaysia \\ ${ }^{4}$ Faculty of Administrative Science \& Policy Studies, Universiti Teknologi MARA Sarawak, Samarahan, \\ Malaysia \\ Correspondence: Zaherawati Zakaria, Faculty of Administrative Science \& Policy Studies, Universiti Teknologi \\ MARA Kedah, 08400 Merbok, Kedah, Malaysia. Tel: 60-4-442-4312. E-mail: zaherawati@kedah.uitm.edu.my
}

Received: July 4, 2012 Accepted: July 29, 2012 Online Published: October 19, 2012

doi:10.5539/ass.v8n13p153 URL: http://dx.doi.org/10.5539/ass.v8n13p153

\begin{abstract}
This paper aims to make a comparative analysis of Malaysia's nation-building process and critically look at these programs; namely the Rukun Negara, Bangsa Malaysia and 1Malaysia by looking at three main angles; ideology, race and ethnicity as the nation-building components. Initial survey has found out that tolerant government compromise to integrate the multiracial Malaysian has contributed to the problems. Even though the recent trends show there is a tendency of Malaysian to be 'colour blind' due to some kind of democratization and freedom of information access, still however, it did not show any sign that racial politics will disappear for good. Its unique compositions that based on multiracial, multi-religious, multicultural and multilingual as well as geographically divided has been identified by many scholars as an obstacle to the construction of Bangsa Malaysia. Several efforts from Rukun Negara (national ideology), Bangsa Malaysia and the latest, 1Malaysia have been and are being made by the government in realizing the prospect but no avail. The question now, how the Malaysian-style of racial accommodation will survive, is the nation-building program have been sufficient enough to dispose racial sentiments among the multiracial Malaysian, and if it is not, what should be happening.
\end{abstract}

Keywords: Malaysian politics, consociationalism, primordialism, nationalism, communalism, nation state, nation-building

\section{Introduction}

Since its year of independence, Malaysia has come to many glorious achievements and accomplishments. Its stability in politics has always been the solid platform for any advancements and extraordinary achievements in all aspects of life including social, economy, development, education and even sports.

Malaysia's capability has established its name as the new economic power of Asia and becomes a rapid developing country. This is something amazing and out of expectation. Malaysia has got its status in just a short period of time as the result of a very influential relationship between the leaders and the people. The multi-racial Malaysian is generally enjoying a better life than before independence. While in the international arena, the "mutual benefits and peaceful co-existence" of foreign policy adoption has continued to create a positive impact for Malaysia (Hilley, 2011). Hence, it is not surprising when Malaysia is often recognized as an example of a multi-racial developing country and often has been referred to by other developing countries.

Unfortunately, this success does not leave any significant impact to the relationships between ethnic in Malaysia. After 55 years of independence, relationship among the major ethnics has maintained its status quo that has been inherited before the formation of modern Malaysia. Although various approaches and several integration programs have been implemented, and some of them are still moving in progress, there are no signs that the 
compositions would be eroded and the formation of Malaysian nation-state will be realized.

Although at the surface level, the relationship between ethnic in Malaysia may be deemed to be quiet, it could be just a layer of camouflage and deem as 'cosmetics'. Deep in the bottom, a strong stream of anger, frustration, discontentment and hatred between ethnic flows hardly and possibly creating a racial dichotomy that persisted nearly every aspects of life. This dichotomy is always painted with suspicion, mistrust and hatred over ethnocentric feeling that eventually sharpen the feeling of primordial. All of these have led to the creation of soaring competition among the ethnic. As a result, almost all aspects of socio-economic and socio-politics in Malaysia are often portrayed in terms of zero-sum competition between the Malay and non-Malays.

Thus, the Rukun Negara (National Ideology), Bangsa Malaysia (Malaysian nation-state) and the latest 1Malaysia concept are among the programs of nation building which were forwarded by the government as an effort to reduce the radical racial politicking, and then to form a national integration. In the mean time, this paper also tries to scrutinize whether all of those unity concepts have sufficient ingredients and remedies in forming national integration and assimilation which is compatible with the socio-political landscape of Malaysia. Therefore, in examining the problem, several queries have to be answered. Compared to its neighbouring countries, the Malaysian nation-building is still far from its anticipated objective. Therefore, how far a loose racial accommodation which is underlying the relationship of its people will continue to survive and are the unity concepts have enough impacts in building a targeted Malaysian nation-state.

\section{Historical Background of Ethnic Relations in Malaysia}

An interesting part to be looked into in understanding the socio-politics of Malaysian society is their ability to continuously live in a state of stable tension (Shamsul Amri, 2009). This situation is formed according to a long and unique historical mould, and it is parallel with the development of Malaysia as a multi-ethnic country. What he meant by stable tension is the nature of relationships between ethnic in Malaysia who are always switching on and off, alternately. However, it still happens in a harmonious atmosphere which does not place any massive impact to the survival of the nation's socio- economic interest and status.

Taking into account the background of Malaysia as a colonized country, the formation of multi-ethnic society of its demography is not something natural and voluntary. Its formation has a very close knot with the impacts of colonization and development of British colonial capitalism that exploits the natural resources and economy so as to feed the industrial needs and demands of the western countries. Thus, the existence of a plural society in Malaysia can be summed up as a forced historical process, mainly on the Malay states in the peninsula. To make it worse, the British had implemented a different approach and recognition of the Malays as the indigenous (native), while the non-Malays as immigrants. As a result, it has sharpened the racial sentiments and competitions in almost every aspect of life, especially after Malaysia gained its independence.

In this regard, many scholars blamed the actions of divide and rule policy by the British as a main factor to the problem. A simple variable is taken into consideration as to support the view that British as a government systematically separated the three major ethnics in Malaya, almost in all sectors, namely economy, employment, education and even their homes. To make matters worse, almost no serious effort has been taken by the British government to integrate the separated ethnic, directly or indirectly. There is no doubt to admit that these arguments are true, but to accept it as the main reason to the problem of ethnic plurality in Malaysia is something too linear and simplistic.

Taking into account that the process of racial polarization in Malaysia is a product of long historical process, unnatural and forced, it has to be acknowledged that several other elements have contributed to the problem as well. One of the reasons is the fact that the influx of other ethnic to re-settle in Malaya has long existed since the days of Malacca Sultanate. This demonstrates that the formation of a plural society in Malaysia is not an overnight process (Mohd Yusoff Hashim, 1989). Therefore, a deep understanding of history could help to answer any questions which arose with the existing issue, holistically and more focussed. In this discussion, these three factors have been identified to play a vast role in shaping the polemics of ethnic relationship in Malaysia: the role of Malay traditional politicians as the native known as Bumiputera (literal translation; the son of the soil), the role of immigrants (Chinese and Indians) and the role of British as the colonial master.

The role and contribution of Malay traditional politicians as the native have placed a big impact in the formation of a plural society in Malaysia. This happens because of the existing Malaysia's political and governmental system is associated with the adaptation of British modern bureaucracy. If to analyse, Malaysia's system of constitutional monarchy, which is meant to reduce the absolute power over the reign of the King, is a continuity of political characteristics of feudal government institution. This has been proved by looking at the mobility of Malaysian politics which is moving vertically and forming a dichotomy of power where the King is still regarded 
as a symbol of authority and legitimacy.

This retention has always been associated with the traditions and customs of the Malays which looked passive and submissive. In line with Wittfogel (1957) idea of Orient Community or the Asiatic Society that tends to be despotic, the position of the King as the centre power is often unchallenged in all aspects of administration. Moreover, the dichotomy of power between leaders and the king in administrative system forms in a pyramid and moves vertically in dynamic and harmonious flows. Therefore, the king as the centre power usually forms a high fidelity control over ordinary people. Compared to the Western monarchy, the absolute power is held and monopolized by the king as the centre focus of the power. Thus, the retention of Malaysia constitutional monarchy system which exists today is only symbolic and ceremonial.

The traditional political system in Malaysia is more dynamic compared to the western monarchy. This is because of the existence of a buffering group consisting of the local leaders whose role is to poise up the relationships between the king and the people. The local leaders/chiefs always acknowledged the king as a source of legitimacy, while the king looks at them as a symbol of sovereignty and under his mastery. Furthermore, the allegiance between the leaders and king had been nurtured and decorated with mystical aspects like myth, religion and tradition, in which then been transferred to the people. Consequently, the relationship between the king, local leaders and crowded citizens has created a dyad social networking which formed through the practice of patronage.

The continuation of traditional political values is still moving on and now even more strengthened in Malaysia's modern political context. Although the modern political element was introduced, there is no sign that the old political values have been eroded from being practiced. It is believed to be a neo-feudalism in which the old political customs have been reconstructed in the new political practices. Chandra Muzaffar (1979) and Ahmad Nidzamuddin (2002) believed that the elements of neo-feudalism are maintained in the new political practices, and it is strengthened through the practice of patronage and construction of hegemony. Ironically, the elements are just being transferred to the new entity. In this case, the Malay seems to change their loyalty and fidelity from the king to a new political entity known as United Malay National Organization (UMNO). Automatically, it has also twisted the traditional role of the king as a symbolic protector to the Malay merely into a substantive protector.

The influx of immigrants has to be considered as well when discussing ethnic plurality in Malaysia. Taking into account that its economic growth and strategic geographical location in the centre of international trade route, plus it links to the West and East had made Malaysia as the best region for emigration (diaspora). At the beginning, the diaspora process was only moving around the Malay archipelagos but then it has expanded when the mass migration of Chinese and Indian communities into the Malay world had stimulated the process of ethnic plurality and diversity (Roff, 1957).

At the beginning, ethnic plurality was not really a problem to Malaysia. This was due to the prosperous economic growth which had been shared together by all ethnic. At the same time, the immigrants managed to assimilate themselves by merging their own original culture with the indigenous culture of the Malay. In this case, there was a pattern of the same culture and identity based on the version of dominant group; for instance, the existence of Baba Nyonya community and Malay-Peranakan which were originally from Chinese and Indian communities. These communities have absorbed Malay's customs and traditions in their daily lives.

The problem worsened during the massive influx of the second-generation immigrant workers from Southern China and India brought by the British in order to meet economic demands in Malaya. The label was given by Dr Mahathir (Malaysia's $4^{\text {th }}$ Prime Minister) due to the strong attachment between the immigrants and their homeland and they had separated themselves apart from the local. In difference with the first generation immigrants who can assimilate well with the local community, this generation was considered chauvinistic because they were just coming for wealth as to bring back to their country (Mahathir 1995: 36). Worse still, the centralization of economic sector in the name of productivity enhancement had made them reside in separation and did not share the same stance of live with the locals. Therefore, efforts taken in developing race solidarity as a way to build up the nation state was hard to be realized (Mahathir 2005: 4).

The colonization in Malaya had contributed to the existence of race plurality. Although British was the dominant colonizer in Malaya and shaped its present-day socio-political setting, the power of other colonizers has also contributed to the problem of race plurality. Among the major implications of the British colonization was the issue of massive influx of second generation of immigrants, mostly Chinese and Indians which were imported to support the business and industry of tin and rubber. At the same time, the contribution of other colonizers such as Portuguese, Dutch, and Japanese, and even under the temporary domination of the Communist Party of Malaya 
(CPM) after the defeat of Japan during World War II also had shaped the landscape of the current race relationships. In this case, Short (1997: 10) explained how the Japanese occupation and the action of CPM had aggravated the relationship between races in Malaysia as the favouritism of Japanese that oppressed and discriminated against the Chinese. They (Chinese) then had produced Malayan People's Anti Japanese Army (MPAJA) and formed CPM which was fully supported by their community. CPM's violence on Malays had seen as a last attempt of revenge and resentment against the Japanese's cruelty towards the Chinese community. As a result, there is a feeling of sceptical and antagonistic between Chinese and traumatized Malays for that incident.

British had also brought in changes and revolution to Malaya's political system by introducing the democracy practices and a modern and systematic institutional bureaucracy. By taking the advantage of a loose relationship between the king and local leaders, British had gloriously introduced a new political system which was based on autonomy and circulation of elites. This implementation had been employed mainly to the kings and local leaders, and it had benefited British in all ways (Gullick, 1958). This had facilitated the process of control and colonization of British over states in Malaya which then opened a larger opportunity for them to continue exploiting the economic resources. In a way to fully exploit the economic resources of Malaya, British introduced a centralization of works as an effort to maximize the productivity of the country. Unfortunately, this intention had worsened the problem of race plurality in Malaya.

Almost all questions on the race plurality problem in Malaysia will be associated with the Malay political system, British's contributions and the role of immigrants. The development of relationship between ethnic in Malaysia is surrounded by the three mentioned implications. In the beginning, the process of plurality had not contributed to any ethnic conflicts, but then, it had exploded in 1969. Before that year, the relationship between the ethnics had fluctuated and seemed to be like a game of tug-of-war. In this regards, the racial tension occurred in 1969 when there was a tug-of-war game of relationship between ethnics in Malaysia. This has been worsened by the insertion of different class interaction and, along with the ethnical survivor and interests in their political articulations.

Interestingly, the racial chaos had taken place just after the existence of Malaysia as an independent nation state. Despite the turbidity of racial relationship before independence, it had not contributed to any chaos and riot. Even since then, they have implemented several kinds of unity programs as they hope to settle the problem and bring back the harmonious environment. What is certain, unity and integration are the two sacred words in appreciation of a plural society in Malaysia. In fact, both words have been acknowledged to the stage of social mantra before the National Ideology (Rukun Negara) had been introduced by Tun Abdul Razak as an effective yet systematic approach in developing national unity and integration. This initiative was taken after the tragedy of 1969.

Several programs on nation building had come into progress after the implementation of National Principles. Among the prominent implementations are the idea of Malaysian Nation and the latest 1Malaysia concept. These two national inspirations symbolized a tall interest of national leaders towards unity and integration, and besides, they wanted to make it a reality. Because it is highly esteemed, there is a sort of presumption that this is actually a hasty action for a quick and temporary solution. This is proven by looking back at the history of Malaysia's socio-political environment before independence, where it was a totally uncontrolled and disconcerted event. The problem of race plurality has been here for such a long time and it has surrounded many aspects like polarization of ethnic, economy and even politics since the existence of Malacca Sultanate era.

\section{Comparing Rukun Negara, Bangsa Malaysia \& Malaysia Concept: Fundamental Issues in the Nation Building Programs in Malaysia}

Assuming that unity and integration do not exist in a vacuum condition, it has initiated Malaysia to form its own design and process. It is best to know that consensus democracy or known as consociationalism as coined by Ian Lustick (1979) is responsible in designing the relationship between ethnic in Malaysia (Mujibu, 2009). In fact, it is systematically and efficiently arranged in the Constitution of Malaysia when the agreed social contract between the political elites and the society had chosen consocional politics as a basic foundation in forming the constitution (Mujibu, Zaliha \& Badrul, 2011).

Explaining the matter, the indication given by Furnivall as 'do mix but do not combine' has fulfilled the characteristics of the constitution. This is because; it only allows a mixing process through informal or unofficial premises without considering the larger picture of the whole problem. The dividing lines here are the consideration of ethnic, religion, customs, social, occupation and even residence. As for instance, in the Constitution of Malaysia, there is a specific clause for Bumiputera (literal translation: son of the soil) and a common clause for general reference, and this has been referred interchangeably. In fact, Furnivall's argument on 
the formation of ethnic plurality which has been shaped by the action of local leaders that encouraged the economical migration on the interest of colonizers seemed suitable to be applied in Malaysian context.

Although Furnivall referred to Burma (Myanmar) and Indonesia in formulating the concept of plural society, there are common features of Malaysia with the proposed concept. The common features lied on the definition of plural society as "people who are characterized by division and conflict between human groups which are under a political system" (Furnivall, 1948). Although this concept explains the ethnicity of the Netherlands-India (Indonesia) under the Dutch colonization, many believe that it is a basic literature in discussing the issue of race plurality. In fact, Hefner (2001: 2) assumes that similarities between Malaysia and Indonesia as a plural community has been developed based on the "two or more elements of social orders which live side by side, yet without mingling, in one political unit' (Hefner, 2001: 4).

Hefner looks at the concept of plural society proposed by Furnivall as a concept which has been driven by the approach of neo-classical economy. This has changed the assumptions of Adam Smith's classical economy approach on the notion of culture hegemony and adapted the perception with the new concept of market exchange in the Asian context. In explaining this matter, Smith's assumption has shown that the importance of market in creating a public order to a plural society is a little bit difficult to be operated on in the colonial community in Asia compared to the western society. This is because of the conditions of the Asian multiethnic community which has always been in conflict and only interacted while doing business and exchanging goods at the market (Hefner, 2001: 6).

By criticizing Furnivall has 'overlooked' on the issue due to his efforts of trying to apply the western chauvinism approach that only focused on market liberalization as a key interaction of a plural community. Hefner showed that diversity in cultures has nothing to do with the impact of western colonization only, but if racial problem is meant to be settled, the interest of conflicted groups has to be handled well. Pluralism has to be adjusted as an attempt to create a civilized society. The ideas of democracy have to include the historical weaknesses by assuming that the exchange market will create a utopia in the matter of racial problems (Hefner, 2001: 47-48).

Hefner's view has valid reasons in scrutinizing the relationship between ethnic in Malaysia. Development of Malaysia as an independent nation state is founded by the retention of unity in diversity. Taking into account the unity process is based on liberal democracy and the history of race plurality, market approach alone has no extra answers to fix the problem of race plurality in the context of a nation's development. In addition, Malaysia's independence, in the vicinity of 1950s and 1960s, showed the tendency of post-colonial countries to set up a system of authoritarian rule. This tendency is closely related to the condition of heterogeneous post-colonial countries and has no political consensus, nor any social standard in feeding the prerequisites to the development of a stable and democratic political system. Countries such as Indonesia and Burma (now Myanmar) have taken the approach in developing their nation state by implementing tight control over the issue.

Different from the other Southeast Asia post-colonial countries, Malaysia has not implemented any assimilation enforcement in solving the issue of segregation. Indonesia and Thailand for instance, are the best example to look at when we talk about the enforcement of assimilation in building their nation state. They had implemented a forced assimilation and amalgamation practices in uniting their people, and run through the idea of interventionist. They knew that by combining several ethnics in a wholly eternal culture and identity would lead to a new problem and even worse, racial segregation. Taking Thailand as an example, the process of absorbing minorities of Thai into a custom which stands to make Buddhism as a prerequisite agreement had made the Malay minority in the Southern of Thailand rebelled for independence. Meanwhile, Bhinneka Tunggal Ika, which was meant to celebrate multiple ethnic unity as the foundation of Indonesian Nation, had turned to the lost of Indonesian's identity, affected by the extreme acculturation process and globalization factor.

In view of the uniqueness of each ethnic and its separated and segmented plurality, it is a kind of high risk for Malaysia to implement the same method of strained assimilation and amalgamation in building the nation state. Mujibu et al. (2011: 36) deduces by looking at the almost equal composition of ethnics, plus the equivalent of advantages, strengths and weaknesses between them reckon that this idea is irrelevant to be implemented. In essence, Mujibu et al. (2011) looked at the race plurality as a problem which is always related to the conflicts between ethnics. This is because every different ethnic has its own stage of economy, profession and different place of settlement. In fact, this matter would be worsened, when there is ethnic which always see themselves as being oppressed by other ethnics.

To strengthen the above statement, Ahmad Nidzamuddin (2002: 40) also agreed with the argument forwarded by Mujibu et al. In the study, he found that inequity of political values has worsened the conflict of ethnic, if it is based on the factor of material and primordial. He added, based on this reason, it has to be considered that an 
accommodation and the existing differences could be balanced up through the process of harmonious and transparent bargaining. Therefore, the choice of consensus democracy is an option in a context of no choice as the basis of Malaysia's formation of nation state as it is different from the other Southeast Asia countries.

However, Dr. Mahathir sees the weaknesses of democracy itself has contributed to the problem of building a nation state, especially in a state where the societies are plural in numbers and separated based on ethnics, religions, cultures, economy and even houses (2009b). This is explained by looking at the democracy as:

"Democracy is not the easiest way to govern a country. More often than not it fails to bring about stability, much less prosperity. It is disruptive because it tends to encourage sudden changes in policies and directions with each change in government" (Dr. Mahathir, 1995: 9).

It is seen that the establishment of National Principles (Rukun Negara), which is designed to create a central focus of a nation state in which the main principles act as to guide the directions of race relationship in Malaysia, has failed to achieve its objective (Dr. Mahathir, 2005). In his talk of the proposed idea of Malaysian nation, Dr. Mahathir looks at nation state of Malaysia as being proposed because the National Principles only served as a framework which aims to enhance the shared purpose of Malaysian, while this sharing has not benefited to the long-term assimilation process that allows people in Malaysia to team up 'together on something' practically and concretely (2009a).

Colin Abraham seems to agree with Dr. Mahathir's arguments. In his book, he explained the race's unity cannot rely too much on the approach of ideology and philosophy which aims to increase the shared feeling solely, in reference to the implementation of National Principles. Even he rejected the idea of assimilation as the solving approach to the problem of race plurality in Malaysia, he looked at the efficiency of unity concept which has to be expanded where it needs to be routed from the needs and commitment of each ethnic. Abraham explains this through his argument:

'unity can only be durable if it resists on the basis of mutual regard and caring thought in terms of the other party' (Colin Abraham, 2004: 41).

Looking on the development of nation state in Malaysia, the challenges and direction of this process are always contradicting the spectrum of Malays-Muslim and Secular-Modernization (liberal). To understand the paradox, the different commitment of each ethnic in looking at Malaysia's direction as a nation state could help the discussion. Nationalism in Malaysia has always been portrayed from the perspective of Malays versus Non-Malays. Although the race plurality in Malaysia displays the existence of different ethnics and sub-ethnics, this has not been reflected so much during the sharing consensus of certain issues, policies and opinions. Ironically, when it happens, race plurality has integrated and separated accordingly in the perspective of Malays and non-Malays.

These manifestations are often translated through the sense of dichotomy which focuses on the aspect Malay-Muslim and Non-Malay - Non-Muslim (Wan Hamidi, 2011). For instance, the construction of Malaysia's nation state as stated in the constitution seems to have two different provisions to native (bumiputera) non-native (non-bumiputera) and sometimes to Muslim - non-Muslim, alternately. This matter usually existed when the constitutional clause touches something sensitive such as special rights, freedom of religion, language and so forth.

There are three conditions in the process of nation building which have been running in succession, namely through the National Principles (Rukun Negara), Malaysian Nation and 1 Malaysia concept. It is seen that all these three processes are still focussing on the society's basic nucleus of being united in diversity. In building a nation state in Malaysia, history has demonstrated that it faces three main challenges; firstly, the difficulty in uniting other cultures to be assimilated with one dominant culture. In this case, inequity and equity of ethnic composition is the main obstacle in implementing it. Despite the existence of Peranakan community as a result of this process, we have to know that it started long before Malaysia's independence.

Secondly, the obstruction is also seen in the complexity of forming a new culture derived from other cultures through the complete process of integration. Despite the implementation of accommodation and acculturation as a main channel, it has no big impact as it only occurs ceremonially and at the surface level. For instance, the borrowing-behaviour of other cultures' senses, actions and even customs such as food and traditional costumes, only occurred on the surface level without any shared feeling over the sharing process. Sometimes, it crosses the norm of conventional practices and customs, for instance, intermarriage between race and sharing in celebration like Kongsi-Raya (Chinese-Malay) and Deepa-Raya (Indian-Malay). It is found that this only happen in the stage of realization of the differences, hence the consideration of respecting and being tolerant of others' norms and 
collective sense are to be considered. After the excitement and phenomenon have gone, they will pave their way back to normal.

The last resistance, which makes the process of nation building in Malaysia seems difficult to progress is the strength of implemented concept of unity. The National Ideology, Bangsa Malaysia and 1 Malaysia concept are facing dilemma in constructing a firm framework of a nation. The main challenge is on the existence of cultures diversity, and each of them is striving hard to preserve their own and no one wants to assimilate with other cultures. At the same time, primordial elements such as religion and race are toughly followed and considered as taboo in their respective groups.

\section{Conclusion}

Discourse of nation building and integration of ethnic in Malaysia is often considered too superficial and the important aspects of its process are always ignored. By taking into account the basic of "4As"; Assimilation, Accommodation, Acculturation and Amalgamation as the essential process in building a nation state, every program has to consider all these elements and as well as scrutinizing the implementation, and make it flows in the same direction with the unique demographic background of ethnics in Malaysia. This is meant to create not only a popular program but the one with full contribution and appreciation of the people, and not only as a rhetorical ideology of politicians in gaining power. The concept of National Principles, Malaysian Nation and 1 Malaysia has to be forwarded as the long-term vision and mission, and also the last aim of Malaysia's journey in prospering the harmonious, stable and sustainable political environment.

\section{References}

Abraham, C. (2004). The Naked Social Order: The Root of Racial Polarisation in Malaysia. Subang Jaya: Pelanduk.

Ahmad, N. S. (2002). Budaya Politik Dalam Masyarakat Majmuk Malaysia. In A. M. Yaacob \& S. Mohamad (Eds.), Etika dan Budaya Berpolitik dari Perspektif Islam. Kuala Lumpur: IKIM.

Chandra, M. (1979). Protector? An Analysis of the Concept and Practice of Loyalty in leader-led Relationships Within Malay Society. Penang: ALIRAN.

Furnivall, J. (1948). Colonial Policy and Practice: a Comparative Study of Burma and Netherlands India. New York: New York University Press.

Gullick, J. (1958). Sistem Politik Bumiputera Tanah Melayu Barat. Kuala Lumpur: Dewan Bahasa dan Pustaka.

Hefner, R. (2001). The Politics of multiculturalism, pluralism and citizenship in Malaysia, Singapore and Indonesia. Honolulu: University of Hawaii Press.

Hilley, J. (2001). Malaysia Mahathirism, Hegemony and The New Opposition. London: Zed Books.

Ishak, S. (2007). Sejarah Politik Melayu Pelbagai Aliran. Shah Alam: Karisma Publication.

Lustick, I. (1979). Stability in Deeply Divided Societies: Consociationalism versus Control. World Politics, 31(3), 325-344. http://dx.doi.org/10.2307/2009992

Mahathir, M. (1995). The Malaysian System of Government. Kuala Lumpur: Utusan Printcorp.

Mahathir, M. (2005). National Unity. In Perdana Discourse Series (pp. 4-6). No. 1/2005. Shah Alam: UPENA \& Perdana Leadership Foundation.

Mahathir, M. (2007). Media and National Development. In Perdana Discourse Series (pp. 1-12). No. 6/2007. Shah Alam: UPENA \& Perdana Leadership Foundation.

Mahathir, M. (2009a). Bangsa Malaysia. In Perdana Discourse Series (pp. 1-29). No. 8/2009. Shah Alam: UPENA \& Perdana Leadership Foundation.

Mahathir, M. (2009b). The Role of the Executive, Legislative, Judiciary and Constitutional Monarchy in the Governing of Malaysia. In Perdana Discourse Series (pp. 1-14). No. 9/2009. Shah Alam: UPENA \& Perdana Leadership Foundation.

Muhammad, Y. (1989). Kerajaan Melayu Melaka. Kuala Lumpur: Dewan Bahasa \& Pustaka.

Mujibu, A. M. (2009). Politik Permuafakatan: Satu Analisa Terhadap Amalan Politik di Negara-negara Bermasyarakat Majmuk. Voice of Academia Academic Series of Universiti Teknologi Mara Kedah, 4(2),1-19. 
Mujibu, A. M., Zaliha, H. H., \& Badrul, A. M. (2011). Perubahan Generasi dan Perkembangan Demokrasi di Malaysia Pasca Pilihan Raya Umum ke-12. In M. A. Sani, \& A. R. A. Aziz (Eds.), Agenda Ketahanan Nasional Malaysia (pp. 31-58). Sintok: Institut Pemikiran Tun Dr. Mahathir (IPDM), UUM.

Shamsul, A. B. (2009). Melestari Perpaduan, Memperkukuh Integrasi: Konsep Satu Malaysia sebagai Wahana Terkini. In Kumpulan Dokumen-dokumen Seminar Gagasan Satu Malaysia: Kesinambungan Satu Perjuangan. Kuala Terengganu: Kerajaan Negeri Terengganu \& Universiti Malaya.

Short, A. (1977). The Communist Inssurection in Malaya 1948-1960. London: Ian Allan Limited.

Wan, H. H. (2011). Malaysia Milik Kita Bersama Perjuangan 45 Tahun Parti Tindakan Demokratik (DAP). Kuala Lumpur: DAP Malaysia.

Wittfogel, K. (1957). Oriental Despotism: a Comparative Study of Total Power. New Haven: Yale University Press. 